DOI No: http://dx.doi.org/10.29228/Joh.41929

Makale Türü: Araştırma makalesi

Geliş Tarihi: 25.02.2020

Kabul Tarihi: 24.08.2020

On-line Yayın: 30.08.2020
Article Type: Research article

Submitted: 25.02 .2020

Accepted: 24.08 .2020

Published Online: 30.08 .2020

Atıf Bilgisi / Reference Information

Çelik, O.T. \& Akar, H. (2020). Öğretmen Güçlendirme için Öğretmen Güçsüzlügüünü Anlama. Journal of History School, 47, 2533-2563.

\title{
ÖĞRETMEN GÜÇLENDİRME İÇİN ÖĞRETMEN GÜÇSÜZLÜĞÜNÜ ANLAMA ${ }^{1}$

$$
\text { Osman Tayyar ÇELIK }{ }^{2} \text { \& Hüseyin } \text { AKAR }^{3}
$$

$\ddot{\mathbf{O} z}$

$\mathrm{Bu}$ nitel araştırma öğretmen güçsüzlüğünün kaynaklarını ve duyuşsal bileşenlerini öğretmen görüşlerine dayalı olarak belirlemeye çalışır. Bu sayede öğretmen güçlendirme için geliştirilecek politika ve uygulamalara farklı bakış açıları sunar. Açıklayıcı durum çalışması olarak desenlenen araştırmanın katılımcılarını maksimum çeşitlilik örneklemesi ile belirlenen, Kilis ilinde görev yapan 20 öğretmen oluşturmaktadır. Araştırmanın verileri yarı yapılandırılmış görüşme formu ve kapalı uçlu soru formuyla toplanmıştır. Yarı yapılandırılmış görüşme formunda katılımcı öğretmenlere sınıf içinde, okul içinde ve mesleğe bağlı olarak sosyal hayatlarında yaşadıkları güçsüzlük duyguları üzerine sorular sorulmuştur. Kapalı uçlu soru formunda ise katılımcı öğretmenlere güçsüzlük yaşadıkları durumlarda deneyimledikleri duygular sorulmuştur. Verilerin analizinde içerik analizi ve frekans analizinden yararlanılmıştır. Araştırma sonucunda; mesleğin statüsü ve özellikleri, okul kültürü ve iklimi, okul müdürlerinin yönetim tarzı, öğrenci özellikleri, okul koşulları ve kaynaklar, veli tutum ve davranışları, eğitim ve öğretmen politikaları, bireysel faktörler bağlamında mesleki yeterlik ve iş aile çatışması öğretmen güçsüzlüğüne yol açabilecek faktörler olarak belirlenmiştir. Ayrıca araştırma bulguları güçsüzlük yaşanan duruma bağlı olarak kadercilik, boyun eğme, geri çekilme ve kaygı duygularının öğretmen güçsüzlüğünün duyuşsal bileşenleri olduğunu göstermektedir.

Anahtar Kelimeler: Öğretmen, Öğretmen Güçlendirme, Öğretmen Güçsüzlüğü, Öğretmen Görüşleri.

\footnotetext{
${ }^{1}$ Makale yazımı yazar etki oranı: 1.yazar: \%50, 2. yazar: $\% 50$

2 Dr. Öğr. Üyesi İnönü Üniversitesi, Sağlık Bilimleri Fakültesi, otayyar44@gmail.com Orcid: 0000-0003-3951-7261

${ }^{3}$ Dr. Öğr. Üyesi, Kilis 7 Aralık Üniversitesi, Muallim Rıfat Eğitim Fakültesi, Eğitim Yönetimi Anabilim Dal, huseyinakar@kilis.edu.tr Orcid: 0000-0002-0453-6465
} 


\title{
Understanding Teacher's Weakness for Teacher Empowerment
}

\begin{abstract}
This qualitative research attempts to determine the sources and affective components of teacher's weakness on the basis of teachers' opinions. Thus, it presents different perspectives on policies and practices to be developed for teacher empowerment. The participants of the research, which was designed as a descriptive case study, are comprised of 20 teachers who were selected via the maximum variation sampling and working in Kilis Province. The data of the research were collected by means of a semistructured interview form and a closed-ended questionnaire. Participating teachers were asked questions about their feelings of weakness they experienced in the classroom, in the school and in their social lives due to their profession. In the closed-ended questionnaire, participating teachers were asked about their feelings in case of a weakness. Content analysis and frequency analysis were performed for the analysis of the data. As a result of the research, profession's status and characteristics, school culture and climate, management style of school principals, student characteristics, school conditions and resources, parents' attitude and behaviour, education and teacher policies, individual factors in the context of professional competence and work family conflict has been identified as factors that could lead to teacher weakness. Moreover, the findings of the research indicate that their feelings of fatalism, submission, withdrawal and anxiety were the affective components of teacher's weakness depending on the situation of weakness.
\end{abstract}

Keywords: Teacher, Teacher empowerment, Teacher's weakness, Teachers' opinions

\section{GİRIŞ̧}

Eğitim reformu, etkili eğitim öğretim ve öğrenci başarısı denildiğinde ilk akla gelen temel faktör öğretmendir. Buna bağl1 olarak son yıllarda öğretmen güçlendirmeye ilgi artmıştır. Çünkü öğretmen güçlendirme demek, okulun, eğitim sisteminin güçlendirilmesi demektir (Kıral, 2019). Öğretmen güçlendirmenin önemine bağlı olarak bunun nasıl yapılacağı sorusu akla gelmektedir. Bu kapsamda alan yazınında yapısal güçlendirme, güçlendirici liderlik uygulamaları ve psikolojik güçlendirme gibi farklı yaklaşımlar çerçevesinde öğretmen güçlendirme ele alınmaktadır (Bogler ve Somech, 2004, Lee ve Nie, 2014). Güçlendirme üzerine yapılan araştırmalarda öğretmen güçlendirmenin örgütsel bağl1lık, örgütsel vatandaşlık davranış1, iş doyumu, iyi oluş gibi pozitif örgütsel davranış değişkenleriyle ilişkili olduğu belirlenmiştir (Altınkurt, Anasız ve Ekinci; 2016; Bogler ve Nir, 2012; Dash ve Vohra, 2017; Jiang, Li, Wang ve Li, 2019; Schermuly, Schermuly ve Meyer, 2011; Taştan, 2013). 
Yapısal güçlendirme ve güçlendirici liderlik uygulamalarının öğretmenlerin içsel motivasyonunu arttıracağı varsayılmaktadır. Ancak öğretmen güçlendirme uygulamalarından önce öğretmen güçsüzlüğünü anlamanın ve güçsüzlük kaynaklarına odaklanmanın doğru önlemlerin ve stratejilerin belirlenmesinde önemli olduğu düşünülmektedir. Nitekim öğretmen güçsüzlüğü ve savunmasızlığı bir gerçektir ve öğretmenlerin iş doyumlarını ve mesleki performanslarını derinden etkilemektedir (Klechtermans, 1996). Alan yazında öğretmen güçsüzlüğü genel olarak işe yabancılaşmanın bir boyutu olarak değerlendirilmektedir. İşe yabancılaşma bağlamında öğretmen güçsüzlüğü yönetimin dışında kalma, sonuçlar üzerinde etkili olamamaya bağlı moral ve motivasyon düşüklüğü (Erjem, 2005) olarak ele alınmaktadır. Öğretmen güçsüzlügünün sosyal hayatta, örgüt içerisinde ve sınıf içerisinde birçok kaynăg 1 olabilir. Bunun yanında öğretmenlik duygusal yönleri ağır basan bir meslektir (Hargreaves, 1998). Bu sebeple öğretmenlerin deneyimlerine bağlı olarak yaşadıkları negatif duyguların, güçsüzlük algılarının önemli bileşenleri olduğu söylenebilir. Bu kapsamda araştırmada ilk olarak öğretmenlerin okul içinde, sınıf içerisinde ve mesleğe bağlı olarak okul dışında güçsüzlük yaşadıkları durumlardan yola çıkarak öğretmen güçsüzlüğünün kaynaklarını belirlemek; ikincisi sübjektif güçsüzlük algısı çerçevesinde öğretmen güçüzlüğünün altında yatan ikincil duyguları ortaya çıkarmak amaçlanmaktadır. Bu araştırmanın öğretmen güçsüzlüğünün ve güçsüzlüğü etkileyen faktörlerin daha iyi anlaşılmasına katkı sağlayacağı düşünülmektedir.

\section{Öğretmen Güçlendirme Yaklaşımları ve Öğretmen Güçsüzlüğü}

Öğretmen güçlendirmeye ilişkin yaklaşımlar ilk olarak işletme yönetimi alanında ortaya çıkan personel güçlendirme kavramına dayanmaktadır. Hawthorne araştırma sonuçlarıyla birlikte örgütte insan ilişkilerine olan ilginin artması örgütsel etkililiği sağlamanın bir yolu olarak personel güçlendirme uygulamalarına ve ilgili araştırmalara yön vermiştir. 1960'lı yıllarda işletme örgütlerinde ele alınmaya başlanan kavram 1980'li y1llardan itibaren okul örgütlerinde de yoğun bir şekilde ele alınmaya başlanmıştır (Klecker, 1996). İşletme literatürüne paralel olarak iki temel yaklaşım, psikolojik ve yapısal güçlendirme, öğretmen güçlendirme araştırmalarında da benimsenmiştir (Maeroff, 1998; Short ve Rinehart, 1992). Son yıllarda ise yapisal güçlendirmenin bir uzantısı olarak güçlendirici liderliğe ilgi artmıştır. Yapılan araştırmalarda güçlendirici liderliğin dönüşümcü liderlik, paylaşımcı liderlik uygulamalarından farklı yönleri ele alınmış (Amundsen ve Martinsen, 2013; Sharma ve Kirkman, 2015), okul örgütleri için çok boyutlu bir yapı olarak kavramsallaştırılmıştır (Blase ve Blase, 1997; Lee ve Nie, 2013). 
Güçlendirmeye yönelik farklı yaklaşımların sinırlılıkları olduğu söylenebilir. Yapısal güçlendirmede çalışanların duygu ve düşüncelerinin geri planda olduğu, sadece yönetsel uygulamalara odaklanıldığı görülmektedir (Kıral, 2019). Psikolojik güçlendirme yaklaşımında ise işin çeşitli yönlerine ve yeterliğe ilişkin pozitif algının içsel motivasyonu sağlayacağı varsayılmaktadır. Benzer şekilde farklı boyutlarda güçlendirici lider davranışları takipçiler üzerinde her zaman istendik etkiyi yapmayabilir. Ayrıca güçlendirmeye ilişkin bu yaklaşımlarda bireysel ve bağlamsal faktörler göz ardı edilmektedir.

Güçsüzlük, alan yazınında özellikle yabancılaşmanın önemli bir boyutu olarak ele alınmaktadır. Soza'ya (2015) göre güçsüzlük farklı yabancılaşma türlerinin ortaya çıkmasının da ilk işaretidir. Yabancılaşma kavramı, Marx'ın yabancılaşmış emek kavramından türemiştir. Marx'a göre birey, ürünü veya emeği kendisinden bağımsız bir biçim aldığında yabancılaşır (Goddard, 1998). Yirminci yüzyılda kısmen sosyologların Marx'ın çalışmalarına duyduğu ilginin yeniden canlanması ile yabancılaşma tekrar ilgi odağı olmuştur. Seeman (1959), yabancılaşmanın çok boyutlu doğasını açıkça ortaya koyan ve kavramı ampirik incelemeye daha uygun hale getiren önemli bir teorik makale yayınlamıştır. Terimin geleneksel sosyolojik köklerini takip ederek ve yabancılaşmayı bireyin kişisel bakış açısıyla ele alarak, yabancılaşmanın beş boyutunu belirlemiştir: güçsüzlük, anlamsızlık, normsuzluk, izolasyon ve kendine yabancılaşma (Hoy, 1972). Marx'ın yabancılaşmaya sosyolojik yaklaşımı objektif yabancılaşmayı, Seeman'ın psikolojik yaklaşımı ise sübjektif yaklaşımı temsil etmektedir.

Marx'a göre, yabancılaşma, tamamen öznel bir fenomen değildir, yalnızca tarihsel değişimlerle aşılabilecek nesnel, toplumsal bir durumdur (Sayers, 2011). Bu bakış açısına göre güçsüzlügün kaynağı, sosyal ve örgütsel koşulların insanı nesneleştiren özellikleridir. Öğretmen güçsüzlüğü de mesleğin ve öğretmenin kurumsal yapıların içerisinde güçsüz bir konuma yerleştirilmesinden kaynaklanmaktadır. Sprague'nin (1992) eleştirel literatürü gözden geçirdiği çalışmasında, öğretmenlik mesleğinin tarihsel olarak düşük statülü meslekler içerisinde konumlandırıldığı ifade edilmiştir. Ayrıca öğretmenlik mesleğinin standartlaştırılarak bir dizi basit işe indirgendiğini, öğretmenlerin parçalara ayrılmış bir işin küçük bir bölümünü yerine getiren işçilere dönüştürüldügünü belirtmiştir. Nitekim her ayrıntısı belirlenmiş öğretim programları öğrenci değerlendirme mekanizmalarının artan standardizasyonu ve bürokratikleşme öğretmenliği uzmanlık gerektiren bir iş olmaktan uzaklaştırmakta, öğretmenin süreç kontrolünü kaybetmesine sebep olmaktadır (Smaller, 2015). Apple ve Teitelbaum (1986) ise öğretmenlerin kurumsal güçler nedeniyle öğretimde işgücü süreci üzerindeki kontrolünü kaybettiklerini, sosyal olarak devre dişı 
bırakıldıklarını ve iş yoğunluklarından dolayı moralsiz olduklarını ileri sürmüştür.

Yabancılaşma teorisinde sübjektif güçsüzlük sosyal-psikolojik yaklaşıma dayanmaktadır. Seeman'a (1991) göre güçsüzlük yapısal koşulların birey tarafından yorumlanması sonucu psişik psikolojik zihinsel bir durum olarak tanımlanmıştır. Bu kapsamda kendini güçsüz hisseden bireyler, kendilerini hayatlarındaki olaylar üzerinde kontrol sahibi olarak görmezler (Dean, 1961; Otto ve Featherman, 1975). Benzer şekilde güçsüzlük yaşayan öğretmenler örgütsel koşulları değiştirmek için yapılabilecek bir şey olmadığını ve çıktılar üzerinde kendi etkilerinden çok aile, eğitim sistemi, kültür ve toplum gibi dış güçlerin etkisinin olduğunu düşünür. Seeman (1972), güçsüzlüğün bilişsel yönlerine odaklanırken duygusal bileşenlerini de içeren bir takım önerilerde bulunmuştur. Seeman (1972) güçsüzlüğün kadercilik, karamsarlık ve kayg1 gibi ikincil duyguları içerdiğini öne sürmüştür. Seeman'ın bu düşüncesini çıkış noktası olarak kabul eden Ten Houten (2016), duygular teorisinden yola çıkarak güçsüzlügün duyuşsal düzeyi için bir model geliştirmiş̧ir. Temel duygular ve bunların ikinci dereceden eşleşmeleri ile oluşan ikincil duyguların oluşturduğu bu modeli test ederek doğrulamıştır (bkz. Şekil 1).

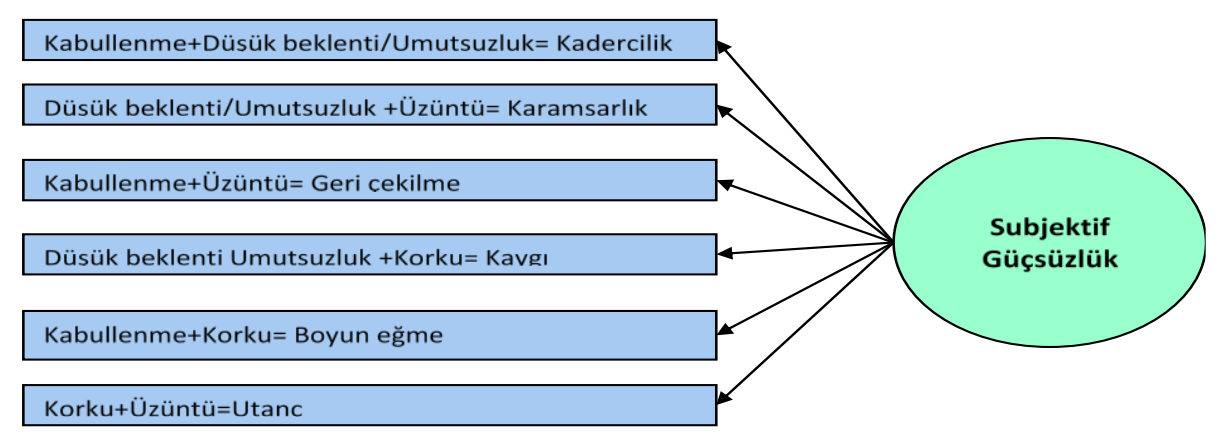

Şekil 1. Ten Houten'ın (2016) Güçsüzlük Modeli

Plutchik'in (1962) temel duygular modelinde kadercilik, karamsarlık ve kayg1 dört temel duygu olarak ifade ettiği üzüntü, korku, kabullenme ve düşük beklentinin ikincil bileşenlerinden oluşmaktadır. Ten Houten (2016) bu dört temel duyguyu farklı şekillerde eşleştirerek üç ikincil duyguyu daha güçsüzlüğün bileşeni olarak ele almıştır. Bunlar geri çekilme, boyun eğme ve utançtır. Bu çalışmada da öğretmen güçsüzlüğü ele alınırken duygular teorisi kapsamında Ten Houten'in (2016) güçsüzlük modeli benimsenmiştir. Modelde ifade edilen ikincil duygulara ilişkin açıklamalar aşağıda yer almaktadır. 
Kadercilik: Sonuçlar ve süreçler üzerinde dış güçlerin etkili olduğuna inanma eğilimidir (Ten Houten, 2016). Kadercilik düşük beklenti ve dişsal kontrol algisı ile karakterize edilebilir.

Karamsarlı: Şartların elverişsiz ve yararsız olduğuna dair beklentiler geliştirme, bir durumu kötü yönleriyle ele alma, olayların hep olumsuz yönde gelişeceğine inanma eğilimidir.

Geri çekilme: Zor durumlarla mücadeleden sonra başa çıkamama sonucu yoğun üzüntü yaşama ve mücadeleyi bırakarak durumu kabullenme duygusudur (Lazarus, 1991).

Kaygl: Geleceğe yönelik zarara uğrama beklentisini içeren, korkunun ateşlenmesi suretiyle ortaya çıkan duygusal tepkidir (Beck, 2005).

Boyun eğme: Gücü elinde bulunduranlara karşı direneme sonucunda kendi duygularını arka plana atarak pasif olma durumudur (Ten Houten, 2016). Boyun eğme aynı zamanda otoriteden korkuyu ve zorunlu bir kabullenmeyi içerir.

Utanç: Olumsuz deneyimlerden sonra bireyin kendini güçsüz ve değersiz hissetme duygusudur (Bugay ve Demir, 2011).

Araştırmada öğretmenlerin güçsüzlük yaşadıkları durumlarda ne tür duygular yaşayabileceğine de odaklanılmıştır. Okul örgütleri toplumsal açık sistemler olup insan ilişkilerinin yoğun yaşandığı yerlerdir. Dolayısıyla okul içerisindeki duygusal deneyimlerin öğretmenlerin inanç, tutum ve davranışlarını şekillendireceği söylenebilir. Bunun yanında öğretmenlik duygusal bir meslektir. Öğretmenlere işlerinde neyi motive edici veya tatmin edici buldukları sorulduğunda, kendiliğinden sevinç, büyülenme, gurur, merak ve coşku duygularına atıfta bulunurlar. Ancak bu duygusal boyutun başka bir tarafı daha vardır. Öğretmenler sadece olumlu duygular yaşamazlar. Öğretmenler, hayal kırıklığı, umutsuzluk, suçluluk ve hatta öfke ve korku duygularını da yaşarlar (Kelchtermans, 1996). Deneyimlenen bu olumsuz duygular öğretmen güçsüzlügünün temel bileşenleri olabilirler.

Son yıllarda öğretmen güçlendirmeye olan ilginin artması aynı zamanda öğretmenlerin güçsüzlük yaşadığının bir kanıtı olarak da değerlendirilebilir. Öğretmenleri karar sürecine katmak, onlara özerklik sağlamak öğretmen güçsüzlüğüne her zaman çözüm olmayabilir. Bunun yerine öğretmenlerin güçsüzlük algısına odaklanmak geliştirilecek politika ve uygulamalara daha fazla katkı sağlayabilir. Bu araştırmada öğretmenlerde güçsüzlük algısına neden olan faktörleri ve güçsüzlüğün altında yatan temel duyguları belirlemek amaçlanmıştır. Bu kapsamda aşağıdaki sorulara cevap aranmıştır. 
- Öğretmenlerden güçsüzlük algısına neden olan faktörler nelerdir?

- Öğretmenler güçsüzlük yaşadıkları durumlarda hangi duyguları deneyimlemektedir?

\section{YÖNTEM}

Öğretmen güçsüzlüğünün kaynaklarını ve altında yatan duyguları belirlemek amacıyla araştırma, nitel araştırma yöntemlerinden durum çalışmasına uygun olarak tasarlanmıştır. Durum çalışması için farklı desenler vardır. Bunlar; betimleyici, açıklayıcı ve keşfedici desendir (Yin, 2018). Bu araştırma açıklayıcı desende kurgulanmıştır. Açıklayıcı durum çalışması, durum için nedensel bir açıklama oluşturmaya yardımcı olarak faktör ve şartların keşfedilmesi ile analiz edilmesine yardımcı olur (Aybek, 2019). Nitekim araştırmada öğretmenlerin güçsüzlügünün altında yatan nedenler keşfedilmeye çalışılmıştır. Araştırmanın analiz birimini katılımcı öğretmenler oluştururken analiz edilecek durum ise öğretmen güçsüzlügüdür.

\section{Katılımcilar}

$\mathrm{Bu}$ araştırmanın katılımcılarını, 2019-2020 öğretim yılının birinci yarıyılında Kilis ilinde görev yapan, araştırmaya gönüllü olarak katılan 20 öğretmen oluşturmaktadır. Öğretmenlerin belirlenmesinde maksimum çeşitlilik örneklemesi kullanılmıştır. Bu örnekleme yöntemi araştırmanın temel amacı çerçevesinde farklı bakış açılarına sahip olabilecek bireylerin örneklemde temsiline imkân sağlamaktadır. Araştırmada cinsiyet, hizmet süresi, görev yapılan okul türü ve yerleşim yeri açısında çeşitlilik sağlanmaya çalışılmıştır. Creswell'e (2017) göre örneklem boyutunu etkileyebilecek birçok faktör vardır. Araştırma deseni, çalışılan olgu kaynakların karmaşıklı̆̆ 1 ve verilerin doyuma ulaşması bunlardan bazılarıdır. Araştırmacılar tarafından önceden katılımcı sayısı belirlenmemiştir. Katılımcıların benzer bilgileri tekrar etmeye başlaması üzerine görüşmeler 20 katılımcı ile sınırlandırılarak sonlandırılmıştır. Katılımcılara ait bilgiler Tablo 1'de sunulmuştur. 


\section{Tablo 1}

Katılımcı Öğretmenlere Ait Bilgiler

\begin{tabular}{lccccc}
\hline S.No & Katılımcı Kodu & Cinsiyet & Hizet Süresi (yıl) & Okul Kademesi & Yerleşim Yeri \\
\hline 1 & Katılımc1 1 & Kadın & 3 & Ortaöğretim & Şehir \\
2 & Katılımc1 2 & Kadın & 18 & Ortaöğretim & Şehir \\
3 & Katılımc1 3 & Erkek & 21 & İkokul & Köy \\
4 & Katılımc1 4 & Kadın & 12 & Ortaokul & Kasaba \\
5 & Katılımc1 5 & Erkek & 2 & Ilkokul & Köy \\
6 & Katılımc1 6 & Kadın & 6 & Ilkokul & Şehir \\
7 & Katılımc1 7 & Erkek & 25 & Ortaokul & Kasaba \\
8 & Katılımc1 8 & Erkek & 11 & Ortaöğretim & Şehir \\
9 & Katılımc1 9 & Erkek & 15 & Ortaokul & Kasaba \\
10 & Katılımc1 10 & Kadın & 1 & Ilkokul & Köy \\
11 & Katılımc1 11 11 & Kadın & 16 & Ilkokul & Şehir \\
12 & Katılımc1 12 & Erkek & 13 & Ortaokul & Kasaba \\
13 & Katılımc1 13 & Erkek & 10 & Ortaöğretim & Şehir \\
14 & Katılımc1 14 & Erkek & 4 & İkokul & Şehir \\
15 & Katılımc1 15 & Erkek & 3 & Ortaokul & Kasaba \\
16 & Katılımc1 16 & Kadın & 19 & Ortaokul & Şehir \\
17 & Katılımc1 17 & Erkek & 5 & Ortaöğretim & Şehir \\
18 & Katılımc1 18 & Erkek & 2 & Ortaokul & Şehir \\
19 & Katılımc1 19 & Kadın & 17 & Ilkokul & Kasaba \\
20 & Katılımc1 20 & Erkek & 22 & İkokul & Kasaba \\
\hline
\end{tabular}

Katılımcıların görev yaptığ Kilis ili Suriye sınırında bir ildir. Dolayısıyla Suriye'li mültecilerin de yoğun yaşadığı bir şehirdir. Bu kapsamda tüm yerleşim yerlerindeki okul kademelerinde mülteci öğrencilere rastlamak mümkündür. Mülteci öğrenciler kapsayıcı eğitim çerçevesinde diğer öğrencilerle birlikte eğitim görme imkânına sahiptir. Bunun yanında sınır bölgesinde olmanın bazı dezavantajları, okulları ve dolayısıyla öğretmenleri de etkileyebilmektedir.

\section{Veri Toplama Araçları ve Süreç}

Araştırmada veri toplama aracı olarak yarı yapılandırılmış görüşme formu ve kapalı uçlu soru formu kullanılmıştır. Yarı yapılandırılmış görüşme formu hazırlanmadan önce alan yazın taraması yapılarak öğretmenlerin güçsüzlük yaşayabileceği durumlar ve alanlara ilişkin bilgi toplanmıştır. Bu kapsamda öğretmenlerin sınıf içerisinde, okul içerisinde ve mesleklerine bağlı olarak gündelik hayatlarında sorun yaşayabilecekleri düşünülmüştür. Sorular, ögretmenlerin belirtilen alanlarda yaşayabilecekleri güçsüzlükleri ortaya 
çıkaracak tarzda açık uçlu olarak düzenlenmiştir. Merriam'a (2013) göre nitel araştırmalarda görüşme soruları daha az yapılandırılmış açı uçlu sorulardan oluşmalıdır. Böylece katılımcılar algıladıkları çevreyi kendi düşüncelerine göre anlatabilirler. Öğretmenlerin sinıf içerisinde güçsüzlük yaşayabilecekleri durumlar için örnek soru "Sınıf içerisinde kendinizi güçsüz hissettiğiniz durumlar/zamanlar oluyor mu?" şeklindedir. Diğer bir veri toplama aracı kapalı uçlu soru formudur. Form, öğretmenlerin görüşmelerde paylaştıkları örnek olaylardan yola çıkarak araştırmacılar tarafından hazırlanan 24 maddelik hipotetik sorulardan oluşmaktadır (örnek sorular için bkz. Ek 1). Her bir araştırma temasına ilişkin üç soru yer almaktadır. Cevap seçenekleri Ten Houten'in (2016) modelindeki üzüntü, korku, kabullenme ve beklenti/umutsuzluk şeklinde dört temel duygudan oluşmaktadır. Öğretmenlerden her bir durumda neler hissedeceklerini belirten iki duyguyu işaretlemeleri istenmiştir.

Görüşmeler 2019 Eylül-Aralık ayları arasında yüz yüze gerçekleştirilmiştir. Katılımcıların kendilerini daha rahat ifade etmesi ve güven amacıyla sorular görüşme öncesinde mail yoluyla katılımcılarla paylaşılmıştır. Görüşme sırasında katılımcılardan ses kaydı için izin istenmiştir. 17 katılımcı ses kaydına izin verirken üç katılımcı izin vermemiştir. Bu üç katılımcının görüşleri not alınmış ve daha sonra kendilerine teyit ettirilmiştir. Görüşmeler sırasında sondalardan da yararlanılmıştır. Sondalar verilerin zenginleştirilmesini ve ek verilerin toplanmasını kolaylaştırır (Yıldırım ve Şimşek, 2008). Bu sayede öğretmenlerin görüşlerini açmaları, belirttikleri durumlarla ilgili anılarını paylaşmaları istenmiştir. Görüşmeler ortalama 25-35 dakika arası sürmüştür. Görüşmeler sonlandırıldıktan sonra kapalı uçlu soru formları aynı katılımcılara çevrimiçi olarak gönderilmiş ve cevaplar elektronik ortamda alınarak kaydedilmiştir.

\section{Verilerin Analizi}

Araştırmada yarı yapılandırılmış görüşme formuyla ve kapalı uçlu soru formuyla elde edilen veriler ayrı ayrı analiz edilmiştir. Öncelikle görüşmelerden elde edilen verilerin analizi yapılmıştır. Nitel araştırmalarda veri analizi ham verilerden anlam çıkarma sürecidir (Merriam, 2013). Ancak nitel analiz çeşitleri ve süreçleri üzerinde araştırmacılar arasında bir fikir birliği yoktur. Genel olarak nitel verilerden anlamlı yapılar oluşturmak amacıyla durum çalışmalarında içerik analizi yapılabilir (Patton, 2014). Nitekim bu araştırmada görüşmelerden elde edilen veriler içerik analizi yöntemiyle incelenmiştir. Bu kapsamda verilerin analizinde ortak olarak takip edilen (Çelik, Baykal ve Kılıç Memur, 2020) (1) deşifre, (2) kodlama, (3) araştırmacı günlüğü yazımı ve (4) kategori oluşturma adımları izlenmiştir. 
Verileri deşifre etmek amacıyla araştırmacılar tarafında ses kayıtları ve görüşmelerde alınan notlar bilgisayar ortamına aktarılmıştır. Bilgisayar ortamındaki verilerle alınan notlar araştırmacılar tarafından iki kez okunarak karş1laştırılmıştır. İkinci aşamada kodlama sürecine geçilmiştir. Kodlama, süreçte önemli bir adımı temsil eder (Schreier, 2014) ve katılımcı görüşlerini tematik bir yapı oluşturmak amacıyla kategorize etmeye yarar (Gibbs, 2007). Kodlama işlemi araştırmacılar tarafından ayrı ayrı gerçekleştirilmiştir. Süreçte deşifre edilen veriler tekrar tekrar okunarak kodlar belirlenmiştir. Araştırmacılar kodlamalarını karşılaştırarak fikir birliğine varmaya çalışmıştır. Bu kapsama bazı kodların silinmesine, bazılarının ise ifade biçiminin değiştirilmesine karar verilmiştir. Veri analizinin üçüncü aşamasında kodlar üzerine odaklanılmış ve notlar alınmıştır. Özellikle kodların nasıl bir araya getirileceği ve nasıl bir soyutlama yapılacağı üzerinde düşünülmüş, süreçte araştırmacılar fikir alış verişinde bulunmuştur. Son aşamada ise kategoriler diğer bir ifadeyle temalar ve alt temalar oluşturulmuştur. $\mathrm{Bu}$ aşamada kodlar temalar altında bir araya getirilmiştir. Tema altındaki kodlar dikkatle incelenmiş, yeni bir temanın altına alınmış ya da farklı bir tema oluşturularak altına eklenmiştir. Kapalı uçlu sorulardan elde edilen veriler ise frekans analizi ile incelenmiştir. Katılımcıların sorularda en sık seçtikleri iki duygu birleştirilerek Plutchik' in (1962) ve Ten Houten (2016) tarafından ifade edilen ikincil duygular belirlenmiştir. Bu duygular temalarla ilişkilendirilerek şekiller halinde sunulmuş ve yorumlanmıştır. Temalar ve alt temalar yorumlanırken doğrudan alıntılara yer verilmiş, doğrudan alıntılar katılımc1 kodları (katımc1 1, katılımc1 2 vb.) ile sunulmuştur.

Araştırmanın geçerliği ve güvenirliği kapsamında araştırma süreci ayrıntılı şekilde sunulmaya çalışılmıştır. Bunun yanında kodlama tutarlığına bakılmıştır. $\mathrm{Bu}$ kapsamda ilgili alandan bir öğretim üyesine deşifre edilmiş veriler sunulmuş ve kodlama yapması istenmiştir. Daha sonra Miles ve Huberman'nın (1994) "güvenirlik=(görüş birliği sayısı)/(toplam görüş birliği+görüş ayrılığı sayıs1)" formülünden yararlanılarak kodlama tutarlığına bakılmıştır. Kodlama güvenirliği \%85,6 olarak hesaplanmıştır. Son olarak aynı alan uzmanı tarafından sonuçların ilgili teorilerle uyumluluğu incelenmiş ve teyit edilmiştir.

\section{BULGULAR ve YORUM}

Verilerin analizi sonucunda sekiz tema belirlenmiştir. Bunlar; meslek olarak ögretmenlik, okul kültürü ve iklimi, okul müdürlerinin yönetim tarzl, veli tutum ve davranışları, okul koşullarl ve kaynaklar, ögrenci özellikleri, eğitim ve ögretmen politikalart ve bireysel faktörler şeklindedir. Temalar, kapalı uçlu 
soruların analizi sonucu elde edilen ikincil duygularla ilişkilendirilerek şekiller halinde sunulmuştur.

\section{Meslek Olarak Öğretmenlik}

Mesleğin öğretmenlerde güçsüzlük algısına yol açan yönleri meslek olarak öğretmenlik teması altında bir araya getirilmiştir. Mesleğin statüsü ve mesleğin özellikleri olarak iki alt tema belirlenmiştir. Tema ve alt temalar, bunlara ilişkin öğretmenlerin deneyimledikleri duygular Şekil 2'de sunulmuştur.

KODLAR

ALT TEMALAR

TEMA

IKINCIL DUYGULAR

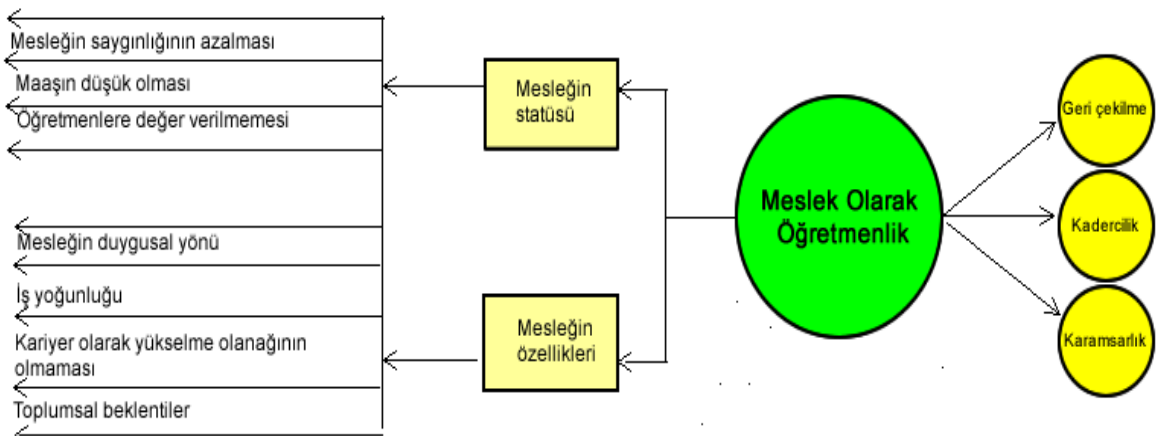

Şekil 2. Meslek Olarak Öğretmenlik Temasına İlişkin Alt Temalar, Kodlar ve Deneyimlenen Duygular

Katılımcı öğretmenler mesleklerine bağlı olarak sosyal hayatlarında güçsüzlük yaşadıkları durumları ifade ederken genel olarak mesleğin statüsü ve özellikleriyle ilgili faktörlere vurgu yapmışlarıdr. Bu kapsamda meslek olarak öğretmenlik teması altında mesleğin statüsü ve mesleğin özellikleri şeklinde iki alt tema belirlenmiştir. Öğretmenler, maaşlarının düşük olmasının, mesleğin saygınlığının ve öğretmenlere verilen değerin azalmasının güçsüzlük algısına yol açtığını ifade etmişlerdir. Nitekim katılımcı 7 başından geçen örnek bir olayı şöyle anlatmıştır: "Üniversitede çalışan bir arkadaşımızın evine misafirliğe gitmiştik. Arkadaşımızın oğlu üniversite tercihinde bulunacakt. Sohbet konusu buraya geldiğinde arkadaş bir dizi meslekleri sıralayı arkasindan şakayla karışık olmadı öğretmen olursun dediğinde çok üzülmüştüm...” Katılımc1 11 ise konuyla ilgili görüşlerini ifade ederken “...insanlara sorsan en kutsal meslek ögretmenlik derler. Ancak ne ögrencilerin ne de toplumun öğretmene değer verdiği yok..." şeklinde öğretmenlere değer verilmediğini ifade etmiştir.

Mesleğin özellikleri alt teması altında katılımcılar mesleğin duygusal yönünün, iş yoğunğunun, kariyer olarak ilerleme firsatının olmamasının ve 
toplumsal beklentilerin kendilerinde güçsüzlüğe yol açtığını ifade etmişlerdir. Kat1lımc1 6 mesleğin duygusal yönünü şöyle ifade etmiştir: “...Illkokul ögretmeniyseniz hasta olsanız da mutsuz olsanız da hayatınız da problemler olsa da sinıfin kapısında birakmak zorundasınız bütün olumsuzlukları. Ancak sinifta bir öğrencinin aç olduğundan başını kaldıramadı̆̆ına şahit olursan, ayakları ıslandiğ ögrrencinizin gözlerinin yaşla dolduğunu gördüysen kendi problemlerini de bir kenara birakiyorsun...." Katılımc1 9 ise toplumun öğretmenlerden çok şey beklediğini, öğretmenliğin sorumluluk gerektiren bir meslek olduğunu bu sebeple güçsüzlük yaşadığını ifade etmiştir.

Meleğin özelliklerine bağlı olarak öğretmenlerin deneyimledikleri duygular geri çekilme, kadercilik ve karamsarlıktır. Bu ikincil duyguların temelinde genel olarak üzüntü, düşük beklenti/umutsuzluk ve kabullenme bulunmaktadır. Sonuç olarak öğretmenlerin mesleğin statüsü ve özelliklerine ilişkin olumsuz algıların negatif duygulara ve buna bağlı olarak güçsüzlük duygusuna yol açacağı söylenebilir.

\section{Okul Kültürü ve İklimi}

$\mathrm{Bu}$ tema altında katılımcıların diğer meslektaş ve yöneticilerle ilişkilerine bağlı olarak güçsüzlük algıları bir araya getirilmiştir. Okul içerisinde paylaşılan değerler ve meslektaş ilişkilerinde okul kültürü ve iklimi önemli bir faktör olması sebebiyle tema, okul kültürü ve iklimi olarak isimlendirilmiştir. Temaya ilişkin kodlar ve deneyimlenen duygular Şekil 3'te sunulmuştur.

KODLAR

TEMA

IKINCIL DUYGULAR

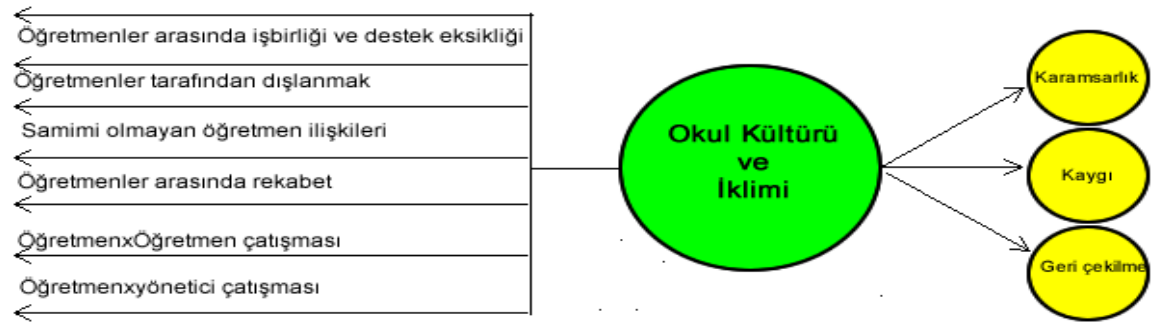

Şekil 3. Okul Kültürü ve İklimi Temasına İlişkin Kodlar ve Deneyimlenen Duygular

Okul kültürü ve iklimi teması altında katılımcılar işbirliği ve destek eksikliği, meslektaşlar tarafından dışlanma, samimi olmayan öğretmen davranışları, örgüt içi çatışmalara vurgu yapmışlarıdır. Katılımcılar özellikle kendileri çatışma yaşamasa da diğer öğretmenler çatışma yaşadığında da 
kendilerini güçsüz hissettiklerini ifade etmişlerdir. Bu kapsamda öğretmenlerin örgüt içerisindeki genel atmosfere duyarlı oldukları kolektif bir duygu oluşturdukları söylenebilir. Katılımc1 19 güçsüzlük yaşamasına sebep olan bir anısını şöyle ifade etmiştir: "Bir mesai arkadaşımla aramızda sorunlar vardı on dakika dinlenmek için ögretmenler odasında girdiğim de bile ya lafla sataşır ya da beni ortamdan uzaklaştırmaya çalışırdı. Haliyle kendinizi güçsüz hissetmeye başlıyorsunuz..." Katılımc1 2 okul yönetimiyle çatışması sebebiyle yaşadı̆̆ 1 güçsüzlük duygusunu şu sözlerle ifade etmiştir: “... Okula her geldiğimde okul müdürü bugün bana ne yaşatacak diye içimden geçiriyorum. Yetkiler onda sorumluluk bizde. İsterse küçücük bir şeyden bile sorun çıkarabilir...”. Katılımc1 8 ise okul ortamına bağlı olarak yaşadığı güçsüzlüğü "Okul ortamında ögretmenler arasında hep bir rekabet kendini üstün görme durumu var. Birlik ve dayanışma adına bir şey yok bu da beni..." ş̧eklinde ifade etmiştir. Okul kültürü ve iklimine bağlı olarak öğretmenlerin deneyimlediği ikincil duyguların karamsarlık, kaygı ve geri çekilme olduğu belirlenmiştir. Bu ikincil duyguların temelinde Ten Houten'ın (2016) güçsüzlük modelinde yer alan dört negatif duygu; korku, kbullenme, düşük beklenti/umutsuzluk ve üzüntü yer almaktadır. Dolayısıyla okul kültürü ve ikliminin birçok farklı duygusal deneyimin önemli bir bileşeni olduğu söylenebilir.

\section{Okul Müdürlerinin Yönetim Tarzı}

Bu tema okul müdürlerinin yönetim tarzına bağlı olarak katılımcıların okul içerisinde yaşadıkları güçsüzlük deneyimlerini ifade etmektedir. Katılımcılarda güçsüzlük algısına yol açan okul müdürü davranışları otoriter ve ilgisiz yönetim tarzı olarak iki alt tema altında incelenmiştir. Tema, alt tema, kodlar ve deneyimlenen ikincil duygular Şekil 4'te sunulmuştur.

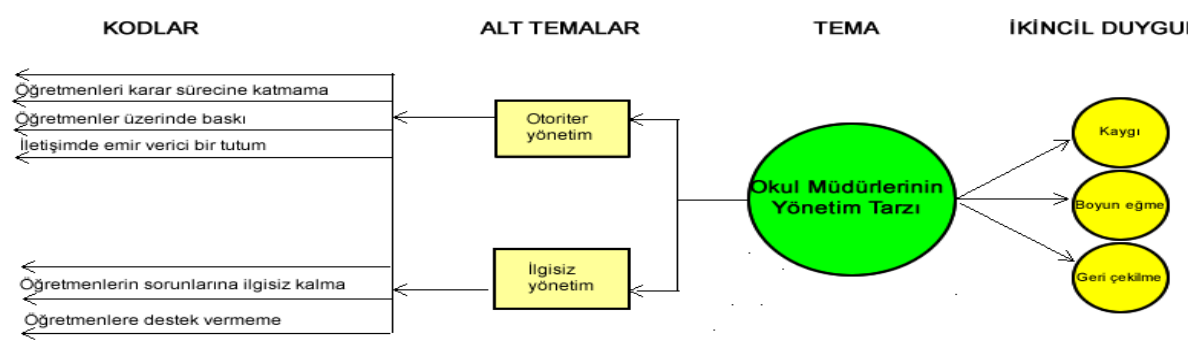

Şekil 4. Okul Müdürlerinin Yönetim Tarzı Temasına İlişkin Alt Temalar, Kodlar ve Deneyimlenen Duygular

Katılımcıların güçsüzlük algısına yol açan durumlar için vurguladıkları önemli bir husus da okul müdürlerinin yönetim biçimidir. Bunlar otoriter ve ilgisiz yönetim tarzıdır. Otoriter yönetim alt teması altında katılımcılar, okul 
müdürlerinin öğretmenleri karar sürecine katmamasını, baskı yapmasını ve emir verici bir tutum sergilemelerini güçsüzlük kaynağı olarak ifade etmişlerdir. İlgisiz yönetim alt teması altında ise katılımcılar okul müdürlerinin öğretmenlere destek vermemesini, öğretmen sorunlarına ilgisiz kalmasını güçsüzlük kaynağı olarak belirtmişlerdir. $\mathrm{Bu}$ temayla ilişkili olarak katılımc1 5 düşüncelerini "Okul ortaminda genel olarak yönetimsel güçsüzlüğ̈̈müz fazla. Okul müdürü bizi okulda siz sadece öğretmensiniz zamanınız geldiğinde konuşun, yerinizi bilin, gibi kelimelerle aşağıllyor. Biz de susmak zorunda kalıyoruz." şeklinde ifade etmiştir. Katılımc 7 ise okul müdürüyle yaşadığı anısını şöyle ifade etmiştir: "Klş günü nöbetçi olduğumuzda okul servisleri için imza listesini şoförler ögretmenler odasina getirsin, yağmurda çamurda ögretmenler için zor oluyor şeklinde bir öneride bulundum. Okul müdür işiniz bu yapacaksınız şeklinde kestirip attı..." Katılımcılar okul müdürlerinin yönetim tarzıyla ilgili cevaplarında korku, kabullenme ve üzüntü duyguları öne çıkmaktadır. Sonuç olarak okul müdürlerinin otoriter ve ilgisiz yönetim tarzlarının öğretmenlerde kaygı, boyun eğme ve geri çekilme gibi olumsuz duygulara yol açacağı söylenebilir.

\section{Veli Tutum ve Davranışları}

$\mathrm{Bu}$ tema katılımcıların velilerin olumsuz tutum ve davranışlarına bağlı olarak yaşadıkları güçsüzlük duygularını ifade etmektedir. Temaya ilişkin kodlar ve katılımcıların deneyimledikleri ikincil duygular Şekil 5'te sunulmuştur.

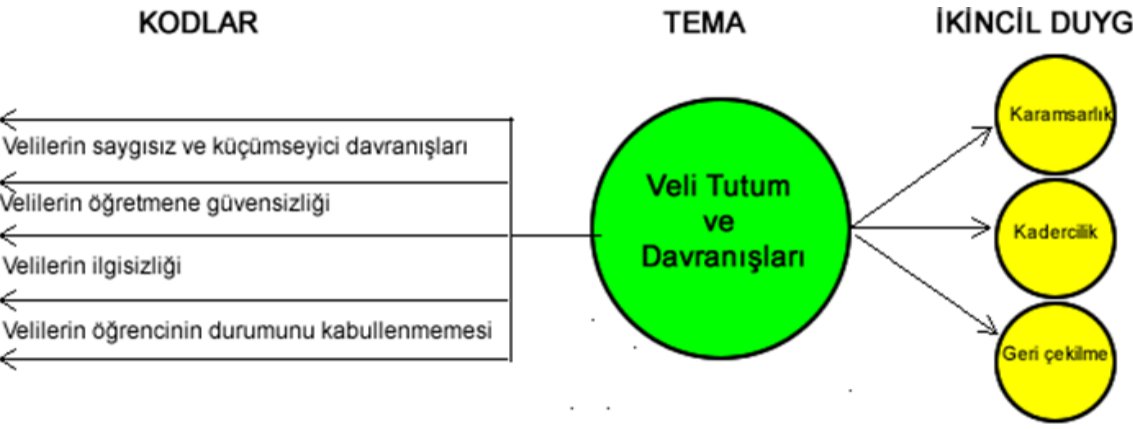

Şekil 5. Veli tutum ve Davranışları Temasına İlişkin Kodlar ve Deneyimlenen Duygular

Velilerin tutum ve davranışları teması altında velilerin saygısız ve küçümseyici davranışları, velilerin öğretmene güvensizliği, velilerin okula ilgisizliği ve çocuklarının durumunu kabullenmemesi katılımc1 öğretmenler tarafindan vurgulanan güçsüzlük kaynaklarıdır. Katılımc1 10, bir veli ile ilgili yaşadığı anısını şöyle ifade etmiştir: "Bir toplantıda velilerden biri haddini aşarak ödevleri nasıl vermem gerektiğine, dersleri nasıl işlemem gerektiğine 
yönelik akıl vermeye kalktı. Tartışma çıktı ve sonunda haklı olmama ră̆men benim vergimle maaşınız ödeniyor şeklinde saygısız ifadelerde bulundu..." Katılımc 3 ise düşüncelerini " Öğretmen olarak çocukların gelişimi için emek vermeye çalışıyorum. Ancak velilerden ilgi görmediğimde bu işin üstesinden nasıl geleceğim diye düşünmeye başliyorum. ” şeklinde ifade etmiştir. Öğretmenler bu durum karşısında umutsuzluğa düşebilir. Öğrencilerin gelişimiyle ilgili karamsarlık yaşayabilir. Nitekim öğretmenler velilerin olumsuz tutum ve davranışları karşısında karamsarlık, kadercilik ve geri çekilme duygusu yaşadığına ilişkin bulgulara ulaşılmıştır.

\section{Okul Koşulları ve Kaynaklar}

Katılımcıların okulun fiziki olanakları ve sınıf koşullarına bağlı olarak yaşadıkları güçsüzlük duygusu okul koşulları ve kaynaklar teması altında bir araya getirilmiştir. Bu temaya ilişkin kodlar ve katılımcıların deneyimledikleri duygular Şekil'6 da sunulmuştur.

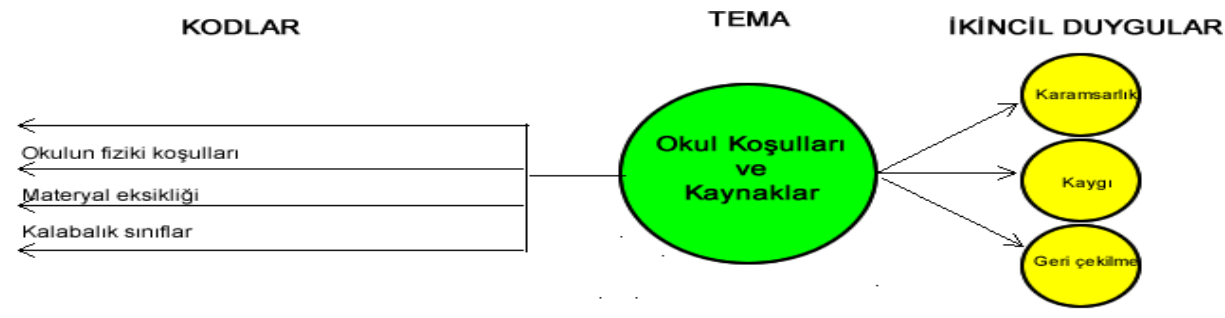

Şekil 6. Okul Koşulları ve Kaynaklar Temasına İlişkin Kodlar ve Deneyimlenen Duygular

$\mathrm{Bu}$ tema altında katılımcı öğretmenler, okulun fiziki koşulları uygun olmadığında, materyal eksikliği olduğunda ve sınıflar kalabalık olduğunda güçsüzlük yaşadıklarını ifade etmişlerdir. Öğretim materyalleri öğrenme için önemli araçlardır. Bunun yanında okulun fiziki olanakları sağlıklı bir öğrenme çevresi için ihtiyaçtır. Bu eksiklikler karşısında öğretmenler istenen amaçlara ulaşabilme noktasında kaygı ve karamsarlık yaşayabilir. Ayrıca kalabalık sınıflarda öğretim konusunda öğretmenler endişe duyabilir. Beş yıllık deneyime sahip katılımcı 17 kalabalık sınıflarda yaşadığı duyguyu "...böyle sinıflarda konuları nasl yetiştireceğim, ögrencilerin her biriyle nasll ilgileneceğim diye diye düşünmeye başllyorum..." şeklinde ifade etmiştir. Nitekim katılımc1 öğretmenler kapalı uçlu sorulara verdikleri cevaplarda korku, düşük beklenti/umutsuzluk ve kabullenme gibi temel duygulara vurgu yapmışlardır. $\mathrm{Bu}$ 
duygular karamsarlık, kaygı ve geri çekilme gibi negatif duygularının bileşenleridir.

\section{Öğrenci Özellikleri}

Katılımcı öğretmenlerin öğrencilere bağlı olarak yaşadıkları güçsüzlük duyguları öğrenci özellikleri teması altında bir araya getirilmiştir. $\mathrm{Bu}$ temaya ilişkin kodlar ve katılımcıların deneyimledikleri duygular Şekil 7'de sunulmuştur.

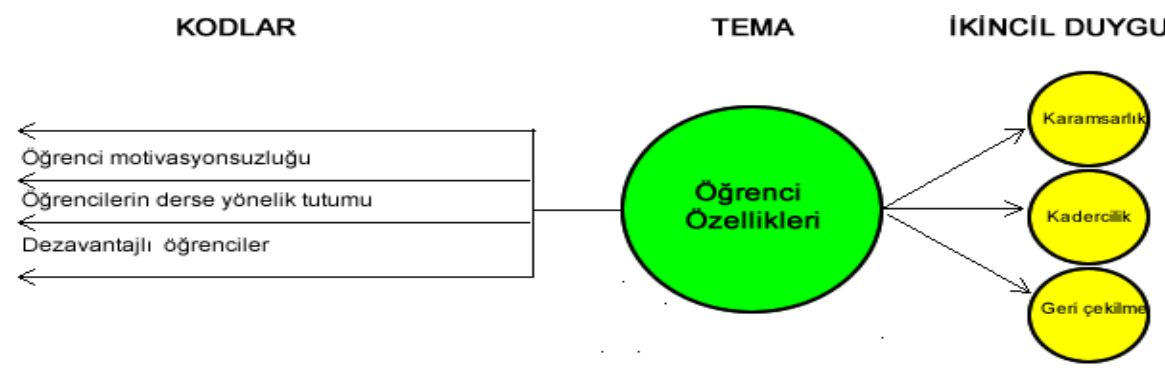

Şekil 7. Öğrenci Özellikleri Temasına İlişkin Kodlar ve Deneyimlenen Duygular

Katılımcı öğretmenler öğrenciler motivasyonsuz olduğunda, derse yönelik ilgisiz olduklarında ve sınıfta dezavantajlı (mülteci, engelli vb.) öğrenciler bulunduğunda güçsüzlük yaşadıklarını ifade etmişlerdir. Özellikle sınıfta çok sayıda göçmen öğrencinin bulunması sebebiyle katılımcı öğretmenler iletişim sorunu yaşadıklarını ifade etmişlerdir. Katılımcı 20 konuyla ilgili düşüncesini “ ... Öğrencilerle asgari düzeyde anlaşmada bile sorun yaşıyoruz. Dolayısıyla dersleri hiç anlamıyorlar. Ne yapacağımı bilmiyorum..." şeklinde belirtmiştir. Katılımcı öğretmenlerin öğrencilerle ilgili bu olumsuz durumlar karşısında karamsarlık, kadercilik ve geri çekilme duyguları yaşadığına ilişkin bulgular elde edilmiştir. Sonuç olarak öğrencilerin ilgisiz ve motivasyonsuz olmaları, sınıfta dezavantajlı öğrencilerin bulunması durumunda öğretmenlerin öğrenci başarısı konusunda düşük beklenti içerisine gireceği ve mevcut durumu kabullenerek geri çekilme duygusu yaşayacağı söylenebilir.

\section{Eğitim ve Öğretmen Politikaları}

Katılımcıların MEB'in politikaları kapsamında yaşadıkları güçsüzlük duyguları eğitim ve öğretmen politikaları teması altında bir araya getirilmiştir. İki alt tema belirlenmiştir. Bunlar değişim ve öğretmen istihdamıdır. Tema, alt temalar, kodlar ve deneyimlenen duygular Şekil 8'de sunulmuştur. 
KODLAR ALT TEMALAR

TEMA IKINCIL DUYGULAR

Şekil 8. Eğitim ve Öğretmen Politikaları Temasına İlişkin Kodlar ve Deneyimlenen Duygular

Katılımcı öğretmenler değişim teması altında MEB'in özellikle değişimin gerçekleştirme biçiminden kaynaklı güçsüzlük algılarına vurgu yapmışlardır. $\mathrm{Bu}$ kapsamda sürekli değişim çabası, plansız değişim ve değişim sürecine katılmama katılımcı öğretmenlerde güçsüzlük algısına yol açan faktörlerdir. Katılımc1 10 konuyla ilgili düşüncelerini şöyle ifade etmiştir: "Gün geçmiyor ki yeni bir uygulamayla karşılaşmayalım. Süreçte bizim fikrimizi kimse sormuyor. Uygulamada bu nasl olur, nasll bir yöntem uygulayalım şeklinde fikrimiz alınmıyor..." . Katılımcı 6 ise konuyla ilgili görüsslerini "Değişim çabasından yorulduğumu hissediyorum. Nasıl bir sistem içerisinde işimizi yürüteceğiz bir kararsızlık var..." şeklinde ifade etmiştir. Öğretmen istihdamı alt teması altında sözleşmeli öğretmenler yaşadıkları güçsüzlükleri ifade etmişlerdir. Bu kapsamda sözleşmeli olarak görev yapan katılımcı öğretmenler, özlük haklarının yeterli olmadığına, sözleşmeli oldukları için okul içerisinde ve sosyal hayatta sorunlar yaşadıklarına vurgu yapmışlardır. Katılımc1 1 konuyla ilgili düşüncelerini “ Öğrencilerinizin gözünde bile sanki gerçek bir ögrretmen değilsiniz. Sözleşmeli ifadesi artık sıfatınız olmuş. İş yerinde meslektaşlarımın bile bana bakış ve davranışlarında bir küçümseme hissediyorum..." şeklinde ifade etmiştir. Katılımc1 15 ise düşüncelerini "Ücretli ögretmenler olsun biz sözleşmeli öğretmen olsun kadrolu öğretmenlerle ayn işi yapmamıza rağmen haklarımız aynı değil. Hatta kadrolu öğretmenlerden daha çok çalıştığımızı söyleyebilirim..." şeklinde ifade etmiştir.

Katılımcı öğretmenlerin bu temaya ilişkin deneyimledikleri duygular utanç, kaygı ve karamsarlık şeklindedir. Sonuç olarak plansız değişimlerin, zayıf özlük haklarının aynı görevi yapan öğretmenlerle farklı statüde görev yapmanın öğretmenlerde temelinde korku, kabullenme ve düşük beklenti duygusu bulunan negatif duygulara yol açacağ 1 söylenebilir. 


\section{Bireysel Faktörler}

Katılımcı öğretmenlerin mesleki yeterlik, iş aile çatışması ve uyum konusunda yaşadıkları güçsüzlük algıları bireysel faktörler teması altında bir araya getirilmiştir. Tema, alt tema ve deneyimlenen duygular Şekil 9'da sunulmuştur.

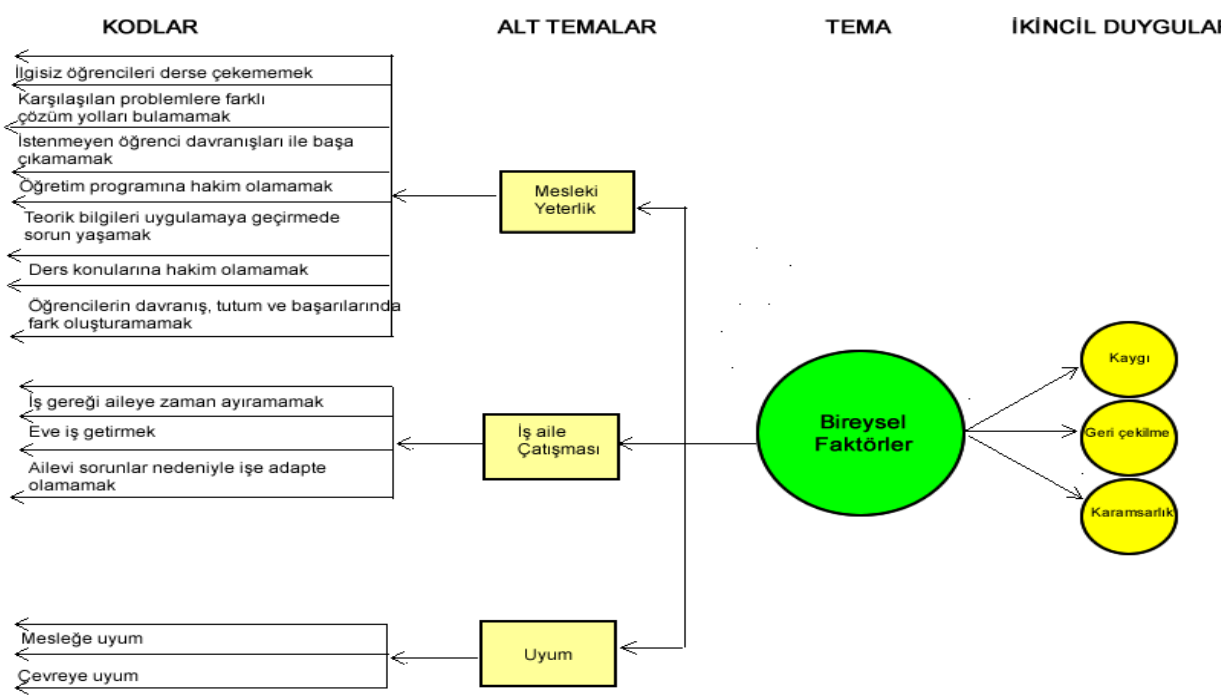

Şekil 9. Bireysel Faktörler Temasına İlişkin Alt Temalar, Kodlar ve Deneyimlenen Duygular

Mesleki yeterlik alt teması altında katılımcı öğretmenlerin mesleki yeterliklerine bağlı olarak yaşadıkları güçsüzlük algıları bir araya getirilmiştir. $\mathrm{Bu}$ alt tema altında katılımcı öğretmenler öğrencilerin dikkatini çekememe, sınıf içerisinde karşılaşılan problemlere çözüm bulamama, istenmeyen öğrenci davranışları ile başa çıkamama, öğretim programına ve ders konularına hâkim olamama teorik bilgileri uygulamaya geçirememe konularına vurgu yapmışlardır. Katılımcıların büyük çoğunluğu özellikle öğrencilerin tutum, davranış ve başarılarında fark oluşturamamaktan kaynaklı güçsüzlük yaşadıklarını ifade etmişlerdir. Teorik bilgileri uygulamaya geçirememe genel olarak hizmet süresi düşük [Katılımc1 1 (3 yıl), Katılımc1 5 (2 yıl), Katılımc1 15 (3 yıl), Katılımc1 18 (2 y1l)] öğretmenler tarafından paylaşılmıştır. Diğer bir alt tema iş aile çatışmasıdır. Bu kapsamda öğretmenler, aileye zaman ayıramamak, eve iş getirmek ve ailevi sorunlar nedeniyle işe adapte olamamak konularına vurgu yapmışlardır. Katılımc1 11 bu konuda düşüncelerini "Evde günün yorgunluğunu atamadan ev işleri ve aileyle ilgilenmek zorunda kalıyoruz. Sinıfta duyduğumuz bütün seslerin ardından evde sese tahammülümüz kalmıyor. Çocuklarımızla oyun 
oynamak bile zor geliyor. Eşinizle konuşmak bazen yorucu olabiliyor. "şeklinde ifade etmiştir. İş aile çatışması kapsamında daha çok kadın katılımcılar görüş bildirmiştir. Uyum alt teması altında özellikle göreve yeni başlayan öğretmenler mesleğe ve çevreye uyum sağlayamamadan kaynaklı güçsüzlüklerine vurgu yapmışlardır. Katılımcı 10 bu konuda düşüncelerini “ İlk günler mesleği birakmak aklımdan geçmişti. Her türlü imkâna sahip bir şehir ortamindan kültürünü bilmediğiniz, coğrafi koşullar zorlu bir yere geliyorsunuz. Bayan olunca adapte olmak daha da zor oluyor... " şeklinde ifade etmiştir.

Katılımcı öğretmenlerin bu temaya ilişkin deneyimledikleri duygular kaygı, geri çekilme ve karamsarlıktır. Sonuç olarak mesleki olarak kendisini yeterli hissetmeyen öğretmenlerin, uyum sorunu ve iş aile çatışması yaşayan öğretmenlerin negatif duygular deneyimleyeceği ve bunun da güçsüzlük algısına yol açacağ söylenebilir.

\section{TARTIŞMA, SONUÇ VE ÖNERILLER}

Öğretmen olmak çoğu zaman duygusal olarak tatmin edici bir iş olarak düşünülür ve öğretmenler öğrencilerin büyümesini ve gelişimini izlemede birçok olumlu deneyim yaşar (Tsang, 2018). Ancak öğretmenler mesleklerine ve iş koşullarına bağlı olarak tükenmişlik, mutsuzluk, stres ve kaygı gibi durumları da yaşarlar. Bu bağlamda öğretmen güçlendirme üzerine son yıllarda ilgi artmıştır. Alan yazınında öğretmen güçlendirme yapısal ve psikolojik güçlendirme (Duman, 2018; İhtiyaroğlu, 2017; Kaya ve Altınkurt, 2018), güçlendirici liderlik (Konan ve Çelik, 2017) bağlamında ele alınmaktadır. Ancak doğrudan öğretmen güçlendirme uygulamalarına odaklanmak yerine öğretmen güçsüzlüğüne odaklamak geliştirilecek politika ve uygulamalara daha çok katkı sağlayabilir. Bu kapsamda araştırmada öğretmen güçsüzlüğünün kaynakları ve öğretmenlerin güçsüzlük yaşadıkları durumda deneyimledikleri duygular ele alınmıştır. Araştırma sonucunda, mesleğin statüsü ve özellikleri, okul kültürü ve iklimi, okul müdürlerinin yönetim tarzı, öğrenci özellikleri, okul koşulları ve kaynaklar, veli tutum ve davranışları, eğitim ve öğretmen politikaları, bireysel faktörler bağlamında mesleki yeterlik ve iş aile çatışması öğretmen güçsüzlüğüne yol açabilecek faktörler olarak belirlenmiştir. Ayrıca araştırma bulguları güçsüzlük yaşanan duruma bağlı olarak kadercilik, boyun eğme, geri çekilme ve kayg1 duygularının öğretmen güçsüzlügünün duyuşsal bileşenleri olduğunu göstermektedir.

Araştırma sonucunda mesleğin statüsü ve bazı özelliklerinin öğretmenler için güçsüzlük kaynağı olduğu belirlenmiştir. Öğretmenlik mesleğinin statüsüne 
ilişkin Türkiye'de yapılan araştırmalarda da mesleğin statüsüne ilişkin öğretmenlerin olumsuz algıya sahip oldukları belirlenmiştir. Çalışıcı Çelik ve Kıral (2018) tarafından yapılan araştırmada öğretmen ve yönetici görüşlerine göre toplumun, yöneticilerin ve velilerin öğretmenlere duyduğu saygının azaldığ 1 tespit edilmiştir. Mutluer ve Yüksel (2019) tarafından yapılan araştırmada ise öğretmenlerin öğretmenlik mesleğinin sosyal statüsü hakkında olumsuz görüşlere sahip olduğu ve öğretmen görüşlerine göre bunda en etkili faktörün mali kazanç olduğu bunun yanında öğretmen istihdamı, eğitim sistemi ve Milli Eğitim Bakanlığı ile öğretmenler arasındaki ilişkilerin de mesleğin sosyal statüsünü olumsuz etkilediği belirlenmiştir. Benzer şekilde Yurdakul, Gür, Çelik ve Kurt (2016) tarafından yapılan araştırmada da öğretmenlerin çoğunluğu yaptıkları işin değerinin anlaşılmadığını ifade etmiş, öğretmenlerin bu durumdan yakınma düzeylerinin yüksek olduğu belirlenmiştir. Öğretmenlik mesleğinden kamuoyu önünde övgüyle bahsedilse de uygulamada öğretmenlere verilen değer konusunda bir tutarsızlık olduğu söylenebilir. Fuller, Goodwyn \& FrancisBrophy'e (2013) göre statüdeki itici güç para ve şöhrettir. Bundan dolayı eğitim, beceri, uzmanlık ve sosyal etki, daha önemli birincil itici güçlere katkıda bulunmamaktadır. Dolayısıyla maddi koşulları iyileștirilmeyen öğretmenlerin statüsünü yükseltme girişimleri etkisiz olmaktadır. Öğretmen güçsüzlügünün diğer bir kaynağı da mesleğin özellikleri ile ilgilidir. Öğretmenlik duygusal yönü ağır basan, iş yoğunluğu fazla ve toplumsal beklentilerin yüksek olduğu bir meslektir. Ayrıca öğretmenlerin kariyer olarak yükselme olanağ 1 da bulunmamaktadır. Öğretmen görüşlerine göre mesleğin bu özellikleri güçsüzlüğe yol açmaktadır. Öğretmenler okul saatleri dışında da işlerine zaman ayırmaktadır. Bu kapsamda derse hazırlık, planlama, sınav kâğıtlarının okunması ve e-okul veri tabanına veri girilmesi bunlardan bazılarıdır. Kaya ve Alım'ın (2015) coğrafya öğretmenleri ile yaptığ 1 araştırmada öğretmenler iş yoğunluğunu stres kaynağ 1 olarak ifade etmişlerdir. Öğretmenlerin mesleğin statüsüne ve özelliklerine ilişkin bu olumsuz algıları sonucunda üzüntü, düşük beklenti/umutsuzluk, kabullenme duygusu yaşayabilecekleri belirlenmiştir. Bu duygular geri çekilme, karamsarlık ve kadercilik gibi negatif ikincil duygularla ilişkilidir. Sonuç olarak deneyimlenen bu olumsuz duyguların öğretmen güçsüzlüğünün duyuşsal bileşenlerini oluşturduğu söylenebilir.

Araştırma sonucunda öğretmen güçsüzlüğünün diğer bir kaynağı okul kültürü ve iklimi olduğu belirlenmiştir. Okul kültürü ve iklimine bağlı olarak işbirliği ve destek eksikliği, dışlanma, çatışma, samimi olmayan öğretmen davranışları öğretmen güçsüzlüğüne yol açan faktörlerdir. İlgili araştırmalarda da okul kültürünün öğretmen moralinin anlamlı bir yordayıcısı olduğu (Özdemir, 2012), öğretmen görüşlerine göre okuldaki insan ilişkilerinin motivasyonlarını 
etkileyen önemli bir faktör olduğu (Ada, Akan, Ayık, Yıldırım ve Yalçın, 2013) belirlenmiştir. Ayrıca okul kültürü ve iklimini, yabancılaşma, iş doyumu, tükenmişlik, moral, bağl1lık, motivasyon ve güven gibi duyuşsal yönleri olan değişkenlerle de ilişkilidir (Asıcı ve İkiz, 2019; Kahveci ve Demirtaş, 2014; Sezgin, 2010). Abasl1 (2018) tarafından yapılan araştırmada örgütsel dışlanma ile yabancılaşmanın güçsüzlük boyutu arasında pozitif yönlü bir ilişkinin olduğu belirlenmiştir. Araştırmada duygusal deneyim bağlamında okul kültürü ve iklimine bağlı olarak öğretmenlerin kaygı, geri çekilme ve karamsarlık gibi negatif duygular yaşayabileceği tespit edilmiştir. Nitekim okul örgütleri insan ilişkilerinin yoğun yaşandığı yerlerdir. Paylaşılan değerler, normlar ve iletişimin niteliği öğretmenleri duygusal olarak da etkileyebilmektedir. Sonuç olarak olumsuz insan ilişkiler öğretmenlerin negatif duygusal deneyimler yaşamasına ve buna bağlı olarak güçsüzlüğe yol açabilmektedir.

Çalışanların moral ve motivasyonlarını etkileyen en önemli unsurlardan biri yöneticilerdir (Argon, 2015). Nitekim araştırmada okul müdürlerinin otoriter ve ilgisiz yönetim tarzlarının öğretmenlerde güçsüzlük algısına yol açtı̆̆ belirlenmiştir. Otoriter yönetici davranışları bağlamında emir verici, baskıcı ve karar sürecine öğretmeni katmayan müdür davranışları karşısında öğretmenler güçsüzlük yaşmaktadır. Ayrıca okul müdürlerinin öğretmenleri desteklememesi, onların sorunlarına ilgisiz kalması da güçsüzlük algısına sebep olmaktadır. Tsang (2019) tarafindan yapılan araştırmada da öğretmenler güçsüzlük kaynağı olarak okul yöneticilerinin sempati eksikliğini ve öğretim koşullarına ilişkin görüşlerini dikkate almamalarını ifade etmişlerdir. Erjem (2005) tarafından yapılan araştırmada ise öğretmenlerin daha çok güçsüzlük kategorisinde yabancılaşma yaşadıkları, özellikle yönetsel süreçlerin önemli bir faktör olduğu belirlenmiştir. Araştırma sonucunda otoriter ve ilgisiz yönetici davranışlarının öğretmenlerde kayg1, boyun eğme ve geri çekilme duygularına yol açabileceği tespit edilmiştir. Kayg1 ve boyun eğme duygusunun temel bileşeni korkudur. Nitekim otoriter yönetim tarzı öğretmenlerde korkuya sebep olabilir. Isherwood ve Hoy'un (1973) çalışmasında baskıcı yapıya sahip okullarda öğretmenlerin daha çok güçsüzlük yaşadığı belirlenirken Argon'un (2015) çalışmasında yönetici özelliklerinin ve yönetsel süreçlerin öğretmenlerin duygu durumlarını etkilediği sonucuna ulaşılmıştır. Karar sürecine katılmayan ve okul yöneticilerden destek görmeyen, otoriter yönetim karşısında öğretmenlerin negatif duygular deneyimleyeceği ve güçsüzlük yaşayabileceği söylenebilir.

Araştırma sonucunda velilerin olumsuz tutum ve davranışlarının öğretmenlerde güçsüzlüğe yol açtığı sonucuna ulaşılmıştır. Velilerin ilgisiz olması, çocuğun durumunu kabullenmemesi ve öğretmenlere güvensizliği ve küçümseyici davranışları öğretmenlerde geri çekilmeye, sonuçlara ilişkin 
kötümserliğe yol açmaktadır. Babaoğlan, Çelik ve Nalbant (2018) tarafından yapılan araştırmada öğretmenlerin ideal veli-öğretmen ilişkisi bağlamında işbirliği, öğretmene sayg1 ve velilerin öğretmene müdahale etmemesi beklentisinde oldukları belirlenmiştir. Veli-çocuk ilişkisi bağlamında ise öğretmenler velilerden çocuklarına daha fazla ilgi göstermesini ve destek olmasını beklemektedir. Şenaras ve Çetin'in (2018) veli baskısı üzerine yaptığı araştırmada ise velilerin ödevler, notlar ve sınıf içi konularda öğretmene müdahale ederek baskı oluşturdukları, bu durum karşısında öğretmenlerin duygusal ve psikolojik sorunlar yaşadığı belirlenmiştir. $\mathrm{Bu}$ araştırmada da velilerin olumsuz tutumları karşısında öğretmenlerin karamsarlık, kadercilik ve geri çekilme gibi negatif duygulara yaşayabileceği belirlenmiştir. Öğretmenler genel olarak öğrenci başarısında velilerin tutum ve davranışlarının önemli olduğunun farkındadırlar. Süreci olumsuz etkileyen veli tutumları karşısında öğretmenler istenen amaçlara ulaşamayacaklarını, durumu değiştiremeyeceklerini düşünerek güçsüzlük yaşayabilirler.

Katılımc1 öğretmenlerin vurguladığı güçsüzlük kaynaklarından birisi de okul koşulları ve kaynaklardır. Bu kapsamda öğretmenler okulun fiziki koşulların, materyal eksikliğinin ve kalabalık sınıfların güçsüzlüğe yol açtığını belirtmiş̧ir. İlgili araştırmalarda da fiziki koşullar, kalabalık sınıflar ve materyal eksikliği öne çıkan sorunlar arasında yer almaktadır (Dağlı ve Han, 2017; Karataş ve Kınalığlu, 2018). Bu sorunlar aynı zamanda öğretmenlerin iş doyumu, tükenmişliği ve motivasyonuyla da ilgilidir. Araştırmada okul koşulları ve kaynakları yetersiz olduğunda öğretmenlerin karamsarlık, kaygı ve geri çekilme duygusu yaşayabileceği belirlenmiştir. Nitekim öğretim için uygun olmayan koşullar, materyal eksikliği amaçlara ulaşma konusunda öğretmenlerde kaygıya, karamsarlığa ve amaçlardan uzaklaşmaya yol açabilir.

Araştırma sonucunda öğrencilerin derse yönelik tutumu, motivasyonu ve sınıfta dezavantajlı öğrencilerin bulunmasının öğretmen güçsüzlüğüne yol açttğg sonucuna ulaşılmıştır. Öğrencilerin derse yönelik tutumu ve motivasyonları başarıları için önemlidir. Çünkü motivasyon ve derse yönelik tutum öğrenmenin ön şartıdır. Katılımcıların görev yaptığı il mülteci öğrencilerin yoğun yaşadığı bir bölgede yer almaktadır. Bu kapsamda öğretmenler iletişim sorunu yaşamakta iletişim kurmakta zorlanmaktadır. Bunun yanında kaynaştırma öğrencilerinin bulunduğu sınıflarda da öğretmenler sınıf düzenini sağlamakta ve öğrencilerin gelişimini desteklemekte güçsüzlük yaşamaktadır. Demir ve Açar (2011) tarafindan yapılan araştırmada da benzer sonuçlara ulaşı1mıştır. Araştırmada belirtilen sorunlar karşısında öğretmenlerin kadercilik, karamsarlık ve geri çekilme duygusu yaşayabileceği tespit edilmiştir. 
Araştırma sonucunda eğitim ve öğretmen politikası bağlamında değişimin ve öğretmen istihdam şekillerinin öğretmen güçsüzlüğüne yol açtı̆̆1 belirlenmiştir. Bireyler için bir işi bilindik yoldan yapmak çoğu zaman güvenlik hissi verir. Öğretmenlerin öğretim şekillerinde ve profesyonel kalıplarında bir değişiklik yapmak bilinmeyenin korkusu ile sonuçlanabilir (Fullan, 2001). Bunun yanında başarısızlıkla sonuçlanan sürekli değişim çabaları öğretmenlerde moral yitimine yol açabilir. Gelişmekte olan ülkeler de olduğu gibi Türkiye'de de eğitim gelişim için bir sıçrama tahtası olarak düşünülmekte ve sürekli reformlar gündeme gelmektedir. Ancak Limon'un (2019) belirttiği gibi Türkiye'de eğitim politikalarında istikrar bir türlü sağlanamamış; gerçekleşen değişikliklerin sonuçları da yeterince takip edilerek değerlendirilememiş̧ir. Katılımcı öğretmenler değişim ve politika belirleme sürecin de görüşlerinin alınmasını istemektedir. Nitekim değişimin uygulayıcıları olarak sürece öğretmeni katmak değişimin başarısı için önemlidir. Özellikle sözleşmeli öğretmenlerin güçsüzlük yaşadığ durum istihdam edilme şekilleridir. Sözleşmeli öğretmenlerin statü algısı düşük olmakta, özlük hakları kadrolu öğretmenlere göre düşük olduğundan güçsüzlük yaşamaktadırlar. Tuncer'in (2012) sözleşmeli ve ücretli öğretmenlerin görüşlerine yer verdiği araştırmada katılımcılar böyle bir istihdam biçimini kölelik ve sömürü olarak nitelendirirken, meslektaşlarının da kendilerine mesafeli yaklaştığını ifade etmişlerdir. Eğitim sistemindeki bu tür politikalar karşısında katılımcı öğretmenlerin daha çok üzüntü ve umutsuzluk ikincil duygu olarak utanç, kaygı ve karamsarlık yaşadıklarını belirlenmiştir.

Araştırma sonucunda bireysel faktörler bağlamında mesleki yeterliğin, iş aile çatışması ve uyumun öğretmenlerde güçsüzlüğe yol açtığı belirlenmiştir. Öğretmenler istenmeyen öğrenci davranışlarıyla başa çıkamadıklarında, öğrenci motivasyonunu sağlayamadıkların, öğrencilerin başarı, tutum ve davranışlarında fark oluşturamadıkların kendilerini güçsüz hissetmektedirler. Özellikle göreve yeni başlayan öğretmenler teorik bilgilerini uygulamaya geçiremediklerinde güçsüzlük algısına yaşadıkları tespit edilmiştir. Yeterlik algısının önemli bir kaynağı olumlu veya olumsuz deneyimlerdir (Bandura, 1983). Dolayısıyla bu olumsuz deneyimlerin öğretmenlerde yetersizlik algisına diğer bir ifadeyle güçsüzlüğe yol açacağı söylenebilir. Kelchtermans (1996) yapmış olduğu araştırmada tüm çabalarına rağmen öğrencilerin başarısında fark yaratamayan öğretmenlerin yetersizlik hissine kapılarak bir kırılganlık yaşadıkları sonucuna ulaşmıştır. Araştırmacı bu deneyimler sayesinde öğretmenlerin mesleki sınırlarıyla karşı karşıya geldiklerini ifade etmiştir. Yazara göre eğitim ve öğretim karmaşık bir süreç olduğundan öğretmenler böylece çabalarının her zaman işe yaramayacağını öğrenir. Öğretmenlerde güçsüzlüğe yol açan diğer bir faktör iş aile çatışmasıdır. Bu durumun temelinde iş yoğunluğu bulunmaktadır. Türker ve 
Çelik (2019) tarafından yapılan araştırmada iş-aile çatışmasının öğretmenlerin iş doyumunu ve yaşam doyumlarını doğrudan etkilediği, aynı zamanda iş aile çatışmasın iş doyumu üzerinden yaşam doyumu üzerinde dolaylı etkiye sahip olduğu belirlenmiştir. İş ve aile bireyin yaşamında iki temel sistemdir. Bu sistemler arasındaki çatışma negatif duygusal deneyimlere ve sonuç olarak bireylerde güçsüzlüğe yol açabilir. Son olarak öğretmenlerde güçsüzlüğe yol açan diğer bir faktörün mesleğe ve çevreye uyum olduğu belirlenmiştir. Uyum sorunu daha çok göreve yeni başlayan öğretmenlerin deneyimledikleri bir güçsüzlük kaynağıdır. Mesleğin ilk yılları öğretmenler için zorlu olabilmektedir. Zorlu coğrafi şartlar, bölgenin kültürel yapısı, teorik bilgileri uygulamaya dökmek, mesleğe alışmak ilk yıllarda karşılaşılan zorluklardan bazılarıdır. Türkiye'de aday öğretmenler üzerinde yapılan birçok çalışmada (Kozikoğlu ve Senemoğlu, 2018; Temiz, 2017) benzer sorunlara değinilmiştir. Araştırma sonucunda öğretmenlerin bireysel faktörler bağlamında yaşadıkları bu sorunların karamsarlık, geri çekilme ve kaygıya yol açabileceği belirlenmiştir.

Araştırma sonuçları göstermektedir ki öğretmen güçsüzlüğünün okul içerisinde, sınıf içerisinde ve okul dışında birçok kaynağı bulunmaktadır. Bu bağlamda örgüt içerisinde sadece birtakım yönetsel uygulamalarla öğretmenleri güçlendirmenin yeterli olmayacağı söylenebilir. Yapısal güçlendirme ve güçlendirici liderlik kapsamında yetki devri, sorumluluk verme, destekleme, mesleki gelişim olanakları sunma, kaynak sağlama, karar sürecine katma (Konczak, Stelly ve Trusty, 2000; Laschinger, Finegan, Shamian ve Wilk, 2001; Lee ve Nie, 2013) gibi güçlendirme uygulamaları sınıf ve okul içerisinde öğretmen güçsüzlüğünün kaynaklarıyla karşılaştırıldığında faydalı olacağı söylenebilir. Bu araştırmadan elde edilen sonuçlar işbirlikçi ve destekleyici bir ortamının okul içerisinde öğretmen güçsüzlüğünü azaltmada önemli bir faktör olacağını göstermektedir. Bunun yanında özellikle sınıf içerisinde öğretmen güçsüzlüğ̈̈nün en önemli kaynağının öğretmenlerin mesleki yeterlikleri olduğu görülmektedir. Bu kapsamda öğretmenlerin mesleki gelişimlerini desteklemek onları güçlendirecektir. Diğer taraftan mesleğin statüsü, eğitim politikaları kapsamında değişim ve öğretmen istihdamı, mesleğe ve çevreye uyum, iş aile çatışması konusunda farklı politika ve uygulamalara ihtiyaç duyulmaktadır. Diğger araştırmalarda olduğu gibi bu araştırmada da mesleki statü kapsamında vurgulanan temel nokta ücrettir. Günümüz koşullarında ücret sosyal statü ve konforlu bir yaşam için itici bir güçtür. Dolayısıyla öğretmenlerin maddi koşullarında iyileştirmeler önemlidir. Bunun yanında Eğitim politikaları geliştirilirken ve uygulanırken öğretmenler süreçte yer almak istemektedirler. Aksi takdirde kendilerini güçsüz hissetmekte ve negatif duygular deneyimlemektedir. Öğretmenleri bu süreçlere katmak yapı içerisinde öğretmeni 
daha güçlü hale getirebilir. Etkili insan kaynakları yönetimi açısından farklı öğretmen istihdam şekillerine son verilebilir. Farklı istihdam şekilleri iş yerinde çalışma barışını da etkilemekte ve öğretmenlerde güçsüzlüğe yol açmaktadır. Araştırma sonucunda öğretmen güçsüzlüğünün kaynağında negatif ikincil duyguların olduğu belirlenmiştir. Bu araştırmada sadece korku, kabullenme, üzüntü ve beklenti/ümitsizlik gibi temel duygular üzerinden öğretmen güçsüzlüğüne odaklanmak bir kısitlılık olarak değerlendirilebilir. Çünkü olaylar karşısında deneyimlenen duygular oldukça farklılık gösterebilir. Bu kapsamda öğretmen güçsüzlüğüne odaklanırken öğretmenlerin farklı duygusal deneyimlerine de odaklanmak hem alan yazına hem de öğretmen güçsüzlüğünü anlamaya katkı sağlayacaktır.

\section{KAYNAKÇA / REFERENCES}

Abaslı, K. (2018). Örgütsel dişlanma, işe yabancılaşma ve örgütsel sinizm Illişkisine yönelik ögretmen görüşleri. Yayımlanmamış doktora tezi, Hacettepe Üniversitesi Eğitim Bilimleri Enstitüsü.

Ada, Ş., Akan, D., Ayık, A., Yııldırım, İ. \& Yalçın, S. (2013). Öğretmenlerin motivasyon etkenleri. Atatürk Üniversitesi Sosyal Bilimler Enstitüsü Dergisi, 17(3), 151-166.

Altınkurt, Y., Anasız, B. T. \& Ekinci, C. E. (2016). Öğretmenlerin yapısal ve psikolojik güçlendirilmeleri ile örgütsel vatandaşlık davranışları arasındaki ilişki. Eğitim ve Bilim, 41(187), 79-96.

Amundsen, S., \& Martinsen, Ø. L. (2014). Empowering leadership: Construct clarification, conceptualization, and validation of a new scale. The Leadership Quarterly, 25(3), 487-511.

Apple, M. W. \& Teitelbaum, K. (1986). Are teachers losing control of their skills and curriculum?. J. Curriculum Studies, 18(2), 177-184.

Argon, T. (2015). Öğretmenlerin sahip oldukları duygu durumlarını okul yöneticilerinin dikkate alıp almamalarına ilişkin görüşleri. Abant İzzet Baysal Üniversitesi Ĕgitim Fakültesi Dergisi, 15(1), 377-404.

Asıcı, E. \& İkiz, F. E. (2019). Okulda öznel iyi oluşun okul iklimi ve öz-yeterlik açısından yordanması. Hacettepe Üniversitesi Eğitim Fakültesi Dergisi, 34(3), 621-638. http://dx.doi.org/10.16986/HUJE.2018038523.

Aybek, E.C. (2019). Durum çalışması. (Çev. Ed. A.Arı). Sosyal Bilimlerde Nitel Araştırma Yöntemleri içinde (323-346). Eğitim yayınevi. 
Babaoğlan, E., Çelik, E. \& Nalbant, A. (2018). İdeal öğrenci velisi üzerine nitel bir çalışma. e-Uluslararası Ĕgitim Araştırmaları Dergisi, 9(1), 51-65.

Bandura, A. (1983). Self-efficacy determinants of anticipated fears and calamities. Journal of Personality and Social Psychology, 45(2), 464-469.

Beck, T. A. (2005). Bilissel Terapi ve Duygusal Bozukluklar. (A. Turkcan, Çev.). Literal yayıncilik.

Blase, J. \& Blase, J. (1997). The micropolitical orientation of facilitative school principals and its effects on teachers' sense of empowerment. Journal of Educational Administration, 35(2), 138-164.

Bogler, R. \& Nir, A. E. (2012). The importance of teachers' perceived organizational support to job satisfaction: What's empowerment got to do with it?. Journal of Educational Administration, 50(3), 287-306.

Bogler, R. \& Somech, A. (2004). Influence of teacher empowerment on teachers' organizational commitment, professional commitment and organizational citizenship behavior in schools. Teaching and Teacher Education, 20(3), 277-289.

Bugay, A. \& Demir, A. (2011). Psychometric properties of the Turkish version of trait shame and guilt scale. Eurasian Journal of Educational Research, 45, 17-30.

Creswell, J. W. (2017). Nitel Araştırmacılar İçin 30 Temel Beceri. (Çev. H. Özcan). Anı yayınc1l1k.

Çalışıcı Çelik, N. \& Kıral, B. (2018). Öğretmenlik mesleğine saygıya ilişkin yönetici ve öğretmen görüşleri. Electronic Turkish Studies, 13(27), 405432.

Dağlı, A. \& Bünyamin, H. A. N. (2017). Öğretmen görüşlerine göre Diyarbakir ili eğitim sorunlari ve çözüm önerileri. Electronic Journal of Education Sciences, 6(12), 108-124.

Dash, S. S. \& Vohra, N. (2019). The leadership of the school principal: Impact on teachers' job crafting, alienation and commitment. Management Research Review, 42(3), 352-369.

Dean, D. G. (1961). Alienation: Its meaning and measurement. American Sociological Review, 26(5) 753-758.

Demir, M. K. \& Açar, S. (2011). Kaynaştırma eğitimi konusunda tecrübeli sınıf öğretmenlerinin görüşleri. Kastamonu Eğitim Dergisi, 19(3), 719-732. 
Duman, Ş. (2018). Ortaöğretim Öğretmenlerinde Psikolojik Güçlendirmenin Yordayıcıları Olarak Yapısal Güçlendirme Yöneticiye Güven ve Lider-Üye Etkileşimi. Yayımlanmamış doktora tezi, Gazi Üniversitesi Eğitim Bilimleri Enstitüsü.

Erjem, Y. (2005). Eğitimde yabancılaşma olgusu ve öğretmen: lise öğretmenleri üzerine sosyolojik bir araştırma. Türk Eğitim Bilimleri Dergisi, 3(4), 395417.

Fullan, M. (2001). Leading in a Culture of Change. Jossey-Bass.

Fuller, C., Goodwyn, A. \& Francis-Brophy, E. (2013). Advanced skills teachers: Professional identity and status. Teachers and Teaching, 19(4), 463-474.

Gibbs, G. R. (2007) Analyzing Qualitative Data (Book 6 of The SAGE Qualitative Research Kit). Sage publication.

Schreier, M. (2014). Qualitative content analysis. U. Flick (Ed). In the SAGE Handbook of Qualitative Data Analysis (170-184). Sage publication.

Goddard, R. D. (1998). The Effects of Collective Teacher Efficacy on Student Achievement in Urban Public Elementary Schools. Unpublished doctoral dissertation, The Ohio State University.

Hargreaves, A. (1998) The emotional practice of teaching, Teaching and Teacher Education, 14(8), 835-854.

Hoy, W. K. (1972). Dimensions of student alienation and characteristics of public high schools. Interchange, 3(4), 38-52.

Isherwood G. B. \& Hoy. W. K. (1973). Bureaucracy, powerlessness and teacher work values. The Journal of Educational Administration, 11(1), 124-138.

İhtiyaroğlu, N. (2017). Yapısal ve psikolojik güçlendirmenin öğretmen motivasyonu üzerindeki etkisi. Kirlkkale Üniversitesi Sosyal Bilimler Dergisi, 7(2), 361-378.

Jiang, Y., Li, P., Wang, J. \& Li, H. (2019). Relationships between kindergarten teachers' empowerment, job satisfaction, and organizational climate: a Chinese model. Journal of Research in Childhood Education, 33(2), 257270.

Kahveci, G. \& Demirtaş, Z. (2014). Örgüt kültürünün örgütsel yabancılaşmaya etkisi örgütsel güvenin aracılık rolü. Turkish Journal of Educational Studies, 1(3), 27-62. 
Karataş, A. \& Kınalığlu, İ. H. (2018). Köy okullarında çalışan sınıf öğretmenlerinin sorunları. Uşak Üniversitesi Sosyal Bilimler Dergisi, 11(3), 207-220.

Kaya, M. F. \& Alım, M. (2015). Coğrafya öğretmenlerinin stres kaynakları. Doğu Coğrafya Dergisi, 20(34), 171-186.

Kaya, Ç. \& Altınkurt, Y. (2018). Öğretmenlerin psikolojik sermayeleri ile tükenmişlik düzeyleri arasındaki ilişkide psikolojik ve yapısal güçlendirmenin rolü. Eğitim ve Bilim, 43(193), 63-78.

Kıral, B. (2019). Eğitim yönetiminde öğretmen güçlendirme. N. Cemaloğlu, M. Özdemir (Ed.), Ë̆itim yönetimi (627-664). Pegem akademi.

Kelchtermans, G. (1996). Teacher vulnerability: Understanding its moral and political roots. Cambridge Journal of Education, 26(3), 307-323.

Konczak, L. J., Stelly, D. J. \& Trusty, M. L. (2000). Defining and measuring empowering leader behaviors: Development of an upward feedback instrument. Educational and Psychological Measurement, 60(2), 301-313.

Konan, N. \& Çelik, O. T. (2017). Okul müdürlerinin güçlendirici liderligine 1liskin ögretmen algisi/teacher perception on the empowering leadership of school principals. Bartın Üniversitesi Egitim Fakültesi Dergisi, 6(1), 322335 .

Laschinger, H. K. S., Finegan, J., Shamian, J. \& Wilk, P. (2001). Impact of structural and psychological empowerment on job strain in nursing work settings: expanding Kanter's model. JONA: The Journal of Nursing Administration, 31(5), 260-272.

Lazarus, R. S. (1991). Cognition and motivation in emotion. American Psychologist, 46(4), 352.

Lee, A. N. \& Nie, Y. (2013). Development and validation of the school leader empowering behaviours (SLEB) scale. The Asia-Pacific Education Researcher 22(4), 485-495.

Lee, A. N. \& Nie, Y. (2014). Understanding teacher empowerment: Teachers' perceptions of principal's and immediate supervisor's empowering behaviours, psychological empowerment and work-related outcomes. Teaching and Teacher Education, 41, 67-79.

Limon, İ. (2019). Eğitim örgütlerinde değişim yorgunluğu, eğitim politikaları bağlaminda moral yitimi ve iş performansl arasındaki ilişki. Yayımlanmamış doktora tezi, Bolu Abant İzzet Baysal Üniversitesi. 
Maeroff, G. I. (1988). The empowerment of teachers: Overcoming the crisis of confidence. Teachers College press.

Merriam, S. B. (2013). Nitel Araştırma: Desen ve Uygulama için bir Rehber. (Çev. Ed: S.Turan). Nobel akademik yayıncılık.

Miles M.B. \& Huberman A.M. (1994). Qualitative Data Analysis. Sage Publications.

Mutluer, Ö. \& Yüksel, S. (2019). The social status of teaching profession: A phenomenological study. Journal of Teacher Education and Educators, 8(2), 183-203.

Otto, L. B. \& Featherman, D. L. (1975). Social structural and psychological antecedents of self-estrangement and powerlessness. American Sociological Review, 40(6) 701-719.

Özdemir, S. (2012). İlköğretim okullarında okul kültürü ile örgütsel sağl1k arasındaki ilişki. Kuram ve Uygulamada Eğitim Yönetimi, 4(4), 599-620.

Patton, M. Q. (2014). Nitel Araştırma ve Değerlendirme Yöntemleri. (Çeviri Editörleri: M. Bütün ve S.B Demir). Pegem akademi.

Plutchik, R. (1962). The Emotions: Facts, Theories and a New Model. Crown Publishing Group / Random House.

Sayers, S. (2011). Alienation as a critical concept. International Critical Thought, 1(3), 287-304.

Schermuly, C. C., Schermuly, R. A. \& Meyer, B. (2011). Effects of viceprincipals' psychological empowerment on job satisfaction and burnout. International Journal of Educational Management, 25(3), 252264.

Seeman, M. (1959). On the meaning of alienation. American Sociological Review, 24(6), 783-791.

Seeman, M. (1991). Alienation and anomie, in Measures of Personality and Social Psychological Attitudes, (Academic Press, pp. 291-371).

Seeman, M. (1972). The signals of' 68: alienation in pre-crisis France. American Sociological Review, 37(4), 385-402.

Sezgin, F. (2010). Öğretmenlerin örgütsel bağlılığının bir yordayıcısı olarak okul kültürü. Ĕgitim ve Bilim, 35(156), 142-159. 
Sharma, P. N. \& Kirkman, B. L. (2015). Leveraging leaders: A literature review and future lines of inquiry for empowering leadership research. Group \& Organization Management, 40(2), 193-237.

Short, P. M. \& Rinehart, J. S. (1992). School participant empowerment scale: Assessment of level of empowerment within the school environment. Journal of Educational and Psychological Measurement, 52, 951-960.

Soza, J. (2015). Teacher Alienation: Reconceptualizing the Educational Work Environment the Faculty of the School of Education. Unpublished doctoral dissertation, Loyola Marymount University.

Sprague, J. (1992). Critical perspectives on teacher empowerment. Communication Education, 41(2), 181-203.

Şenaras, B. \& Çetin, Ş. (2018). Okul müdürleri ile öğretmenlerin algılarına göre ilk ve ortaokullarda veli baskısı: nitel bir araştırma. Milli Ĕgitim Dergisi, 47(220), 157-176.

Taştan, S. B. (2013). The relationship between psychological empowerment and psychological well being: the role of self-efficacy perception and social support. Öneri Dergisi, 10(40), 139-154.

TenHouten, W. D. (2016). The emotions of powerlessness. Journal of Political Power, 9(1), 83-121.

Tsang, K. K. (2018). Teachers' Work and Emotions: A Sociological Analysis. Routledge.

Tsang, K. K. (2019). Teachers as disempowered and demoralised moral agents: School board management and teachers in Hong Kong. British Journal of Educational Studies, 67(2), 251-267.

Tuncer, M. (2012). Türkiye'deki kadrosuz öğretmen istihdamının kadrosuz istihdam edilen öğretmen görüşlerine göre değerlendirilmesi. Gaziantep University Journal of Social Sciences, 11(3), 797-818.

Yildirim, A. \& Simsek, H. (2008). Sosyal Bilimlerde Nitel Araştırma Yöntemleri. Seçkin yayıncılık.

Yin, R. K. (2015). Qualitative Research from Start to Finish. Guilford publications.

Yurdakul, S., Gür, B. S., Çelik, Z., Kurt, T. \& Olçum, A. (2016). Öğretmenlik mesleği ve mesleğin statüsü. Eğitim-Bir-Sen stratejik araştırmalar merkezi. 
EK 1.

\section{ÖĞRETMEN GÜÇSÜZLÜĞÜNE İLISSTIN ÖRNEK HIPOTETIK SORULAR}

1- Okul ve öğrenciler için çabalarınıza rağmen okul yöneticilerinden destek alamadığınızda ne hissedersiniz?

2- Okulunuzda kararlar sadece okul müdürü tarafından alınıp öğretmenler karar sürecine katılmadığında ne hissedersiniz?

3- Okuldaki diğer öğretmenler tarafından dışlandığınızda ne hissedersiniz?

4- Eğitim sisteminde meydana gelen sürekli değişimler karşısında ne hissedersiniz?

5- Okulda öğretmenler arasında işbirliği olmadığı durumda ne hissedersiniz?

6- Çocuğunun yanlış tutum ve davranışlarını kabullenmeyen veli karşısında ne hissedersiniz?

7- Okul yönetimi, veli, toplum ve siyasi güçlerin öğrenci başarısı için baskısı karşısında ne hissedersiniz?

8- Ailenize zaman ayırmanız gerekirken bir taraftan da dersler için hazırlık yapmanız gerektiği durumlarda ne hissedersiniz?

9- Tüm çabanıza rağmen derse ilgisiz kalan öğrenci karşısında ne hissedersiniz?

10- Okulunuzun bulunduğu çevrenin sosyal ve kültürel yapısına uyum sağlamada zorlandığınızda ne hissedersiniz?

$\ldots$

24- Öğrencilerin davranış, tutum ve başarılarında fark oluşturamadığınızı düşündüğünüzde ne hissedersiniz? 